\title{
Charged hydrophilic polymer brushes and their relevance for understanding marine biofouling
}

Wetra Yandi, Sophie Mieszkin, Alessio di Fino, Pierre Martin-Tanchereau, Maureen E Callow, James A. Callow, Lyndsey Tyson, Anthony S. Clare and Thomas Ederth

\section{Linköping University Post Print}

\section{Tweet}

N.B.: When citing this work, cite the original article.

This is an electronic version of an article published in:

Wetra Yandi, Sophie Mieszkin, Alessio di Fino, Pierre Martin-Tanchereau, Maureen E Callow, James A. Callow, Lyndsey Tyson, Anthony S. Clare and Thomas Ederth, Charged hydrophilic polymer brushes and their relevance for understanding marine biofouling, 2016, Biofouling. Biofouling is available online at informaworld ${ }^{\mathrm{TM}}$ : http://dx.doi.org/10.1080/08927014.2016.1170816

Copyright: Taylor \& Francis: STM, Behavioural Science and Public Health Titles http://www.tandf.co.uk/journals/default.asp

Postprint available at: Linköping University Electronic Press

http://urn.kb.se/resolve?urn=urn:nbn:se:liu:diva-127522 


\section{Charged Hydrophilic Polymer Brushes and Their Relevance for Understanding Marine Biofouling}

Wetra Yandi $^{\mathrm{a}}$, Sophie Mieszkin ${ }^{\mathrm{b}}$, Alessio di Fino ${ }^{\mathrm{d}}$, Pierre Martin-Tanchereau, ${ }^{\mathrm{c}, \mathrm{e}}$, Maureen E.

Callow $^{\mathrm{b}}$, James A. Callow ${ }^{\mathrm{b}}$, Lyndsey Tyson ${ }^{\mathrm{c}}$, Anthony S. Clare ${ }^{\mathrm{d}}$, Thomas Ederth ${ }^{\mathrm{a}, *}$

${ }^{a}$ Division of Molecular Physics, IFM, Linköping University, 58183 Linköping, Sweden

${ }^{b}$ School of Biosciences, University of Birmingham, Birmingham B15 2TT, UK

'International Paint Ltd, Gateshead NE10 OJY, UK

[now Akzo Nobel Performance Coatings Research, Gateshead, UK]

${ }^{d}$ School of Marine Science and Technology, Newcastle University, Newcastle NE1 7RU, UK

${ }^{e}$ Department of Applied Sciences, Northumbria University, Newcastle upon Tyne NE1 8ST,

$U K$

*Corresponding author. Email: ted@ifm.liu.se

Published in

Biofouling, 2016

Vol 32, no 6, pp 609-625

DOI: $10.1080 / 08927014.2016 .1170816$ 


\begin{abstract}
The resistance of charged polymers to biofouling was investigated by subjecting cationic (PDMAEMA), anionic (PSPMA), neutral (PHEMA-co-PEG 10 MA), and zwitterionic (PSBMA) brushes to assays testing protein adsorption, attachment of the marine bacterium Cobetia marina; settlement and adhesion strength of zoospores of the green alga Ulva linza; settlement of barnacle (Balanus amphitrite and B. improvisus) cypris larvae; and field immersion tests. Several results go beyond the expected dependence on direct electrostatic attraction; PSPMA showed good resistance toward attachment of C. marina, low settlement and adhesion of $U$. linza zoospores, and significantly lower biofouling than on PHEMA-coPEG ${ }_{10}$ MA or PSBMA after one week of field tests. However, by 8 weeks of field test, there were no significant differences in biofouling coverage among the surfaces. While charged polymers are unsuitable as antifouling coatings in natural environment, they provide valuable insights into fouling processes, and are relevant for studies due to charging of nominally neutral surfaces.
\end{abstract}

Keywords: polymer brushes; surface charge; antifouling surfaces; Cobetia marina; Ulva linza; Balanus spp. 


\section{Introduction}

Once surfaces are exposed to marine environments, an electrical double layer is immediately formed at the interface. This double layer, which is dependent on the surface charge, affects the conditioning of the surface through absorption of dissolved organic material, and also the attachment of marine micro- and macroorganisms such as bacteria, diatoms, blue-green algae, tubeworms and barnacles (Callow \& Callow 2002, Kirschner \& Brennan 2012, Rosenhahn et al. 2010). Some microorganisms secrete sticky extracellular polymeric substances (EPS) which help them to connect together and bind strongly to a surface (Christensen 1989, Poulsen et al. 2014). This assemblage of microorganisms and EPS is referred to as a biofilm, or slime. The presence of biofilms on surfaces may influence the settlement of propagules of higher organisms such as algal spores (Joint et al. 2002, Marshall et al. 2006, Mieszkin et al. 2013, Mieszkin et al. 2012, Patel et al. 2003), larvae of barnacles (Dobretsov et al. 2013, Hadfield \& Paul 2001) and tubeworms (Hadfield 2011, Zardus et al. 2008). The colonization by these organisms on surfaces leads to economic and environmental costs, which have been widely reported (Callow \& Callow 2011, Callow \& Callow 2002, Fitridge et al. 2012, Schultz et al. 2011).

Current research on marine antifouling coatings is focused on developing environmentally benign (non-toxic) coatings to control, prevent or reduce the impact of marine biofouling (Callow \& Callow 2011, Lejars et al. 2012, Rittschof 2010). The fact that propagules of marine fouling organisms settle and attach easily on immersed untreated solid surfaces, while many slimy or gel-like surfaces, such as marine algae (Bhadury \& Wright 2004) and sea anemones (Atalah et al. 2013) are more resistant to epibiosis, has inspired to explore the potential of hydrogels and other highly hydrophilic materials for the control of marine biofouling (Ekblad et al. 2008, Larsson et al. 2007, Yandi et al. 2014), and for informing the development of useful coatings. The prevention of epibiosis of marine organisms is sometimes the combined result of a strongly hydrated surface and, for example, secretion of substances with antifouling activity by the basibiont (Dobretsov et al. 2013, Fusetani 2004, Rickert et al. 2015), continuous production of mucus (Wahl et al. 1998), or other specifically developed antifouling mechanisms. It has also been found that attachment and settlement of marine organisms on synthetic neutral hydrogels or hydrophilic polymers is very low both in laboratory and in marine field tests (up to $1 \mathrm{~h}$ exposure to bacteria or algal spores, $48 \mathrm{~h}$ incubation with barnacle cyprids, up to two months field immersion) (Ekblad et al. 2008, Xie et al. 2011, Yandi et al. 2014, Yang et al. 2012). The antifouling properties in the latter case can be correlated with 
the particular physicochemical properties of hydrophilic polymers, such as high wettability and entropic elasticity (Yandi et al. 2014). However, interactions between fouling organisms and hydrophilic surfaces are influenced also by other parameters, and the presence of charges may facilitate or inhibit macromolecular conditioning, or the early attachment of fouling organisms via electrostatic interactions. For example, it has been reported that the net charge of the cell walls of most fouling bacteria in both freshwater and marine environments is negative (Bereschenko et al. 2010, Mitik-Dineva et al. 2009), as is also the case for the plasma membrane of motile zoospores of the marine macro-alga Ulva linza (Rosenhahn et al. 2009). Furthermore, the EPS secreted by fouling microorganisms typically contains charged polysaccharides and proteins (Christensen 1989, Poulsen et al. 2014, Svetlicic et al. 2013).

The excellent antifouling properties of several charge-neutral hydrophilic materials, including nominally uncharged PHEMA-Co-PEG ${ }_{10}$ MA and zwitterionic PSBMA, is well documented, and has been explained in terms of, for example, steric repulsion, strong hydration, large excluded volumes, or low polymer/water interfacial free energy (Chen et al. 2010). It has also been suggested that charge-neutrality is an essential feature of protein-resistant selfassembled monolayers (SAMs) (Chapman et al. 2000, Ostuni et al. 2001). However, most surfaces, including also nominally neutral materials, become charged to some extent upon immersion in water due to preferential adsorption of ions, ionization, or asymmetric dissociation. It is also clear that zwitterionic materials, where the strengths of the constituent acidic and basic groups are different, have a pH-dependent net charge, with additional secondary effects from the exact composition of the ionic environment. Thus, understanding the effects of surface charge on fouling is also of considerable relevance to the current and intense interest in antifouling charge-balanced materials.

To further understand marine bioadhesion, behavioral responses of the dispersal stages of fouling organisms, and settlement preferences, it is also important to understand the role of surface charge. Studies in our own laboratory (Ederth et al. 2008, Ederth et al. 2009) and also by others (Rosenhahn et al. 2009) have confirmed that the surface charge has a considerable impact on the settlement of zoospores of $U$. linza. Similarly, in studies using different SAMs it was found that settlement of barnacle cyprids of Balanus amphitrite and B. improvisus was higher on negatively charged surfaces, compared to neutral and positively charged SAMs (48 h incubation) (Di Fino et al. 2014, Petrone et al. 2011). Considering that most materials and also natural surfaces are negatively charged in aqueous media, it would be expected that most organisms have adhesion mechanisms adapted to anionic surfaces. 
Cationic polymers have been studied extensively for potential applications in biofouling control in the biomedical field. Inherent antimicrobial activities of cationic polymers have been utilized for contact-active coatings (Ferreira \& Zumbuehl 2009). Chitosan, a cationic polysaccharide, has antimicrobial activity against both Gram-positive and Gram-negative bacteria (Li et al. 2011, Vinsova \& Vavrikova 2008). Other cationic polymers containing derivatives of quaternary ammonium amine (Lee et al. 2004) and imine (Yudovin-Farber et al. 2010), or poly(vinyl- $N$-hexylpyridinium) (Tiller et al. 2001) have also shown antibacterial activity in solution. In comparison to cationic polymers, there are far fewer studies on the effects of anionic polymers on biofouling and these are typically oriented toward biomedical materials (Lei et al. 2014, Lord et al. 2006). However, a recent study on the influence of charge of hydrogels immobilized onto polypropylene (PP) feed spacers for use in nanofiltration membrane systems has shown significant reduction in the attachment of Escherichia coli and delayed growth of biofilms on anionic hydrogel-coated PP, relative to that on neutral and zwitterionic coatings, after seven days of filtration (Wibisono et al. 2015). It was hypothesized that the lower biofouling on anionic surfaces resulted from higher surface wettability and repulsive electrostatic interactions between the anionic polymer and the negatively charged bacterial cell wall. On the other hand, Yang et al. (Yang et al. 2012), reported that anionic poly(sodium styrene sulphonate) was less effective in resisting bacterial attachment (24 h exposure), than neutral or zwitterionic polymers. Yang and collaborators also reported higher settlement of cyprids of $B$. amphitrite on anionic polymers. Beyond these, reports on marine fouling onto charged polymers are few, with a notable exception of the electrostatic attractive interaction between cationic pyridinium polymers and zoospores of $U$. linza (Krishnan et al. 2005).

Here, we perform a systematic study of the cationic polymer PDMAEMA (poly(2dimethylaminoethyl methacrylate)) and the anionic PSPMA (poly(3-sulfopropyl methacrylate)), with the intention of investigating the role of polymer charge on the attachment and adhesion of marine fouling organisms, and to explore properties which are potentially useful for fouling control. These charged polymers are compared to neutral PHEMA-coPEG 10 MA (poly(2-hydroxyethyl methacrylate-co-polyethylene glycol methacrylate)) and zwitterionic PSBMA (poly((sulfobetaine methacrylate)), materials which are well studied in the context of marine fouling, and which also have shown good antifouling properties (Ekblad et al. 2008, Yandi et al. 2014, Zhang et al. 2009). PDMAEMA is a pH- and temperaturesensitive material due to the presence of hydrophilic amino groups, and hydrophobic segments at the end of the side chains (Liu et al. 2007). In acidic solution, PDMAEMA is hydrophilic and 
fully ionized by protonation of the ammonium, and it interacts strongly with surrounding water molecules. Ion-dipole interactions between ammonium ions and water result in formation of a strong solvation (hydration) shell. However, as the $\mathrm{pH}$ increases this interaction is gradually weakened due to decreasing protonation of ammonium groups, resulting in a heterogeneous structure with partial loss of hydration and thus also amphiphilic behavior. This polymer has antimicrobial properties against both Gram-positive and Gram-negative bacteria (Lee et al. 2004, Liu et al. 2007, Rawlinson et al. 2010). The anionic PSPMA has also been reported to reduce bacterial adhesion and to inhibit the growth of bacteria due to high surface hydration resulting from solvation of the sulfonate groups (Guo et al. 2013, Ramstedt et al. 2007), and also result in lower attachment of $E$. coli and delayed growth of biofilm in membrane filtration tests (Wibisono et al. 2015).

PDMAEMA, PSPMA, PHEMA-Co-PEG ${ }_{10} \mathrm{MA}$ and PSBMA were polymerized using surface-initiated atom-transfer radical polymerization (SI-ATRP) at uniform thicknesses (around $100 \AA$ ). Their antifouling properties were studied by adsorption of proteins, attachment of the marine bacterium Cobetia marina, settlement of zoospores of the marine macro-alga $U$. linza as well as barnacle cyprids of $B$. amphitrite and B. improvisus. An 8 weeks static immersion field test assay in a marina was also conducted.

\section{Materials and Methods}

Materials. 2-(dimethylamino)ethyl methacrylate (DMAEMA), 3-sulfopropyl methacrylate potassium salt (SPMA), 2-hydroxyethyl methacrylate (HEMA), polyethylene glycol methacrylate (PEG $10 \mathrm{MA})$, [2-(methacryloyloxy)ethyl]dimethyl-(3-sulfopropyl)-ammonium hydroxide (sulfobetaine methacrylate, SBMA), copper (I) bromide (99.999\%), 2,2-bipyridine (BPY, 99\%) and proteins used for bioevaluation were purchased from Sigma-Aldrich Sweden AB. $\alpha$-bromoisobutyrate-11-mercapto-undecane for the initiator SAMs was purchased from ProChimia Surfaces, Poland. Protein adsorption assays were carried out using $1 \mathrm{x} 1 \mathrm{~cm}^{2}$ silicon wafer pieces. For bacterial attachment, settlement and adhesion strength of zoospores of $U$. linza as well as field test experiments, glass microscope slides (cleanroom-cleaned Nexterion B, $26 \times 76 \times 1 \mathrm{~mm}^{3}$, Schott AG, Germany) were used. Silicon pieces and glass slides were coated with a $25 \AA$ adhesion-promoting titanium layer and subsequently with $300 \AA$ gold by electron-beam evaporation under vacuum. Cyprid settlement assays were carried out in 24-well cell culture plates (Sarstedt, USA) coated with a thin gold layer by simultaneously rotating and tilting the well plates during evaporation, as described previously (Petrone et al. 2011). 
Phosphate-buffered saline (PBS) was prepared by dissolving PBS tablets (Sigma-Aldrich) in $200 \mathrm{~mL}$ of deionized water (Milli-Q water, > 18.2 M $\Omega \mathrm{cm}$, Millipore) and adjusting to $\mathrm{pH} 7.4$ (surface tension $72.4 \mathrm{mN} / \mathrm{m}$ ). Artificial seawater (ASW) for the captive-bubble wettability experiments was prepared by dissolving $24.5 \mathrm{~g}$ of sodium chloride, $4.1 \mathrm{~g}$ of sodium sulfate, $11.1 \mathrm{~g}$ of magnesium chloride hexahydrate, $1.5 \mathrm{~g}$ of calcium chloride dihydrate and $0.7 \mathrm{~g}$ potassium chloride in one liter of Milli-Q water (simplified version of the ASTM standard D1141 (ASTM 2013)). The solution was then adjusted to pH 8.2 with $0.1 \mathrm{M} \mathrm{NaOH}$, and filtered through a $0.2 \mu \mathrm{m}$ pore size membrane filter (Nalgene, USA) (resulting surface tension 73.8 $\mathrm{mN} / \mathrm{m})$. Tropic Marin ASW was used for all biofouling assays.

Preparation of initiator SAMs. Gold-coated sample substrates were cleaned in TL1 solution (1:1:5 proportions of $25 \% \mathrm{NH}_{3}, 30 \% \mathrm{H}_{2} \mathrm{O}_{2}$, and Milli-Q water for $10 \mathrm{~min}$ at $85^{\circ} \mathrm{C}$ ), and after washing several times with Milli-Q water, the surfaces were blow-dried in $\mathrm{N}_{2}$. (Petrone et al. 2011)Cleaned gold substrates were immersed in $50 \mu \mathrm{M}$ solutions of $\alpha$-bromoisobutyrate-11mercapto-undecane in ethanol for $24 \mathrm{~h}$ to form the initiator SAM. After sonication and rinsing with ethanol, the substrates were blow-dried in $\mathrm{N}_{2}$.

Preparation of polymers. A neutral PHEMA-co-PEG ${ }_{10} \mathrm{MA}$ random copolymer and homopolymers of cationic PDMAEMA, anionic PSPMA and zwitterionic PSBMA were prepared via surface-initiated atom-transfer radical polymerization (SI-ATRP) methods. Briefly, the reaction solution of $2.41 \mathrm{mM}$ copper bromide and $4.68 \mathrm{mM}$ 2,2'-bipyridine was placed in a sealed glass reactor in a glove box under $\mathrm{N}_{2}$ atmosphere. Then, $200 \mathrm{mM}$ of degassed monomer solution of HEMA and PEG ${ }_{10}$ MA (molar ratio 1:1), DMAEMA, SPMA, or SBMA in a mixing solvent (Milli-Q water and methanol at a 1:1 volume ratio) was transferred to the reactor, using $3 \mathrm{ml}$ solution per $\mathrm{cm}^{2}$ sample. Gold substrates with initiator-SAMs were then placed into the reactor under $\mathrm{N}_{2}$ protection at room temperature $\left(20^{\circ} \mathrm{C}\right)$ (Figure 1$)$. The polymer films were prepared at a uniform thickness (around $100 \AA$ ) by varying the polymerization time (Table 1). After polymerization, samples were rinsed in running solvent $\left(\mathrm{H}_{2} \mathrm{O} / \mathrm{MeOH} 1: 1\right)$, and then kept in Milli-Q water overnight to leach chemical residues or unreacted monomers, followed by rinsing in running Milli-Q water.

Polymer surface characterization. The chemical structure of the polymers was monitored by Fourier-transform infrared reflection-absorption spectroscopy (FT-IRAS) at a grazing angle of 85․ The spectrometer (Bruker IFS66) was equipped with a liquid nitrogen cooled MCT detector. A deuterated hexadecanethiol $\left(\mathrm{HS}\left(\mathrm{CD}_{2}\right){ }_{15} \mathrm{CD}_{3}\right) \mathrm{SAM}$ on gold was used to record the 
background spectrum. Spectra were baseline-corrected using a 5-iteration concave rubberband method. Film thicknesses were determined using a Rudolph Research AutoEL ellipsometer ( $\lambda$ $=632.8 \mathrm{~nm}, 70^{\circ}$ angle of incidence). The refractive indices of the gold substrates (TL1-cleaned as described previously) were measured before polymerization. To determine the thickness of the polymer layers, a three-layer optical model (ambient/organic film/gold) was used, where the refractive index of the organic film was set to 1.5. Five different spots were measured on each sample and the average was calculated as the polymer film thickness.

Wettability was assessed by static contact angle measurements. Measurements with sessile droplets of deionised water in air, and captive-bubble measurements with air in ASW, were carried out with a CAM 200 Optical Contact Angle Meter (KSV Instruments Ltd., Finland) equipped with a manual liquid dispenser. Contact angles on three water droplets/bubbles were measured on each surface. The surface energies of hydrated polymers were determined by measuring captive-bubble contact angles of $n$-octane and air in deionised water. The latter contact angles were acquired using a Dataphysics OCA35 contact angle analyzer with SCA22 software. Samples were equilibrated in deionized water $(>1 \mathrm{~h})$ before measurement and were then placed facing downwards in a glass cell filled with deionized water. A J-shaped needle was used to release $2 \mu \mathrm{L}$ of an air bubble or n-octane droplet to the surface, using a computercontrolled dispensing system. Three contact angles were measured for air $\left(\theta_{a}\right)$ and $n$-octane $\left(\theta_{0}\right)$ and were averaged. The stated underwater contact angles were measured inside the bubble or n-octane droplet. Surface energies were calculated using the Owens \& Wendt approach (Owens \& Wendt 1969) applied to underwater contact angles (Roudman \& DiGiano 2000). The topography of the dry polymer films was investigated by tapping-mode atomic force microscopy (AFM), over a $2.5 \times 2.5 \mu \mathrm{m}^{2}$ area with an image resolution of 512 x 512 pixels, acquired at a line scan rate of $1 \mathrm{~Hz}$.

\section{Fouling assays}

Protein adsorption. Fibrinogen, lysozyme (net cationic at $\mathrm{pH}$ 7.4) and pepsin (net anionic at $\mathrm{pH}$ 7.4) were used to investigate the effect of charge on the non-specific interaction between polymers and proteins. The initial thicknesses of six replicates of each polymer were determined via ellipsometry prior to the assays. The samples were equilibrated in PBS for $1 \mathrm{~h}$ at room temperature, before protein solutions $(0.4 \mathrm{mg} / \mathrm{mL})$ were added to the samples, and incubated 
for $1 \mathrm{~h}$ at room temperature under static conditions. Samples incubated in PBS without any protein were used as controls, with negligible changes in thickness. After soaking 3 times in PBS and gently blow-drying under an $\mathrm{N}_{2}$ stream, the thicknesses of the samples were remeasured to obtain the adsorbed protein thicknesses.

Attachment of the marine bacterium Cobetia marina. Three replicate slides of each polymer were equilibrated in filtered (0.22 micron) ASW for $1 \mathrm{~h}$ prior to the assay. The bacterial suspension was obtained after the cells were centrifuged and then washed twice to remove excess of EPS for optimal adhesion. The optical density of the bacterial suspension was then adjusted to $0.1 \mathrm{OD}_{600 \mathrm{~nm}}$. Slide samples were removed from the ASW and placed in polystyrene Quadriperm dishes (Greiner Bio-One), followed by addition of $10 \mathrm{~mL}$ of bacterial suspension. The dishes were then placed on a rotary shaker at room temperature for $1 \mathrm{~h}$ at $50 \mathrm{rpm}$ to allow attachment of bacteria to the surfaces. Next, the bacterial suspension was removed and the slides were 'washed' with $10 \mathrm{~mL}$ of filtered ASW for $1 \mathrm{~min}$ at $50 \mathrm{rpm}$ to remove any loosely bound cells. After removing the ASW, the three replicate slides of each polymer were fixed with 10 $\mathrm{mL}$ of $2.5 \%$ glutaraldehyde for $20 \mathrm{~min}$ at room temperature. Slides were then 'washed' in MilliQ water and air-dried. Adhered bacterial cells were stained with $5 \mu \mathrm{M}$ of SYTO ${ }^{\circledR} 13$ (Invitrogen, Molecular Probes, excitation and emission at 488 and $509 \mathrm{~nm}$, respectively), and covered with a glass cover slip ( 22 x 64 mm, VWR International). The slides were then immediately placed in the dark for 10 min. The density of bacterial cells was determined by using an AxioVision 4 image analysis system attached to a Zeiss epifluorescence microscope (40x objective; $\lambda$ excitation and emission: 450/490 and 515/565 nm, respectively) and a video camera. A total of 30 fields of view, each taken at $1 \mathrm{~mm}$ intervals along the slide, was counted for each replicate.

Settlement and adhesion strength of zoospores of Ulva linza. Settlement and adhesion strength assays were performed by following the principles outlined previously (Callow et al. 1997, Mieszkin et al. 2012). Briefly, six replicate slides of each polymer were equilibrated in ASW for $1 \mathrm{~h}$ prior to the assay. After removal of the ASW, the six replicates of each tested surface were placed separately in polystyrene Quadriperm dishes (Greiner Bio-One). Ten milliliters of spore suspension $\left(10^{6}\right.$ spores $\left./ \mathrm{ml}\right)$ were added to each compartment, and dishes were quickly placed in the dark for 45 min to allow zoospores to settle on the tested surfaces under static conditions. Samples were then 'washed' by passing through a beaker of filtered ASW 10 times to remove unsettled (swimming) spores. Three slides of each chemistry were fixed with $10 \mathrm{ml}$ of glutaraldehyde ( $2.5 \mathrm{v} / \mathrm{v} \%$ ) for $20 \mathrm{~min}$ at room temperature for determination of spore 
densities. The samples were then rinsed in filtered ASW, followed by filtered ASW/deionized water (1:1 volume ratio) and then by deionized water in order to remove glutaraldehyde, to be finally air-dried. The number of settled spores was counted by chlorophyll autofluorescence by using AxioVision 4 image analysis system attached to a Zeiss epifluorescence microscope (20 $\mathrm{x}$ objective; $\lambda$ excitation and emission at 546 and $590 \mathrm{~nm}$, respectively). Spores were counted in 30 fields of view, each taken at $1 \mathrm{~mm}$ intervals along the slide, for each of the three replicates. The adhesion strength of the settled spores was determined by exposing the three remaining slides to a wall shear stress of 52 Pa for 5 min in a calibrated water channel (Schultz et al. 2000). The sample slides were then fixed and the spore density was determined as described above. The percentage of spore removal was determined by comparing the number of remaining spores after exposure to the flow channel with that of the unexposed samples.

Settlement of barnacle cyprids. Adults of B. amphitrite (=Amphibalanus amphitrite) (Clare \& Hoeg 2008) (supplied from the Duke University Marine Laboratory, North Carolina, USA) and B. improvisus (=A. improvisus) (supplied from the Department of Biological and Environmental Sciences, Tjärnö, University of Gothenburg, Sweden), which were maintained in separate tanks, were allowed to release nauplii naturally over a period of 3-4 h (B. amphitrite) and 2-3 h (B. improvisus). The larvae were attracted to a cold point light source and collected by pipette. The nauplii were then transferred at intervals to a dilute solution of Tetraselmis suecica for temporary storage until 10,000 larvae of each species had been collected. Nauplii (a mix of stages 1 and 2) were transferred to a clean plastic bucket containing $10 \mathrm{~L}$ of filtered $(0.7 \mu \mathrm{m})$ ASW with $36.5 \mathrm{mg} \mathrm{L}^{-1}$ of streptomycin sulphate and $21.9 \mathrm{mg} \mathrm{L}^{-1}$ of penicillin $\mathrm{G}$ at $28{ }^{\circ}$ C. B. amphitrite larvae were fed with an excess of a mixture of Skeletonema marinoi and Tetraselmis suecica for 5 days until metamorphosis to the cyprid stage. Cyprids were filtered from the culture, transferred into ASW and stored at $6^{\circ}$ C. B. improvisus nauplii were fed a mixture of Thalassiosira pseudonana and T. suecica, which allowed development to the cyprid within 4 days (see Di Fino et al. (2014) for more details). Cyprids were filtered from the culture, transferred into ASW and used immediately for settlement assay. Three-day-old B. amphitrite and 0-day-old B. improvisus cyprids were used in the settlement assays, which used 24-well polystyrene tissue culture plates (Sarstedt, USA). Each well plate was coated with gold followed by grafting of polymers via SI-ATRP as described above. Two milliliters of filtered ASW containing 20 cyprids were placed in each well. The lids were replaced on the plates, wrapped in damp tissue and in tinfoil to minimize evaporation, and subsequently incubated in the dark at $28{ }^{\circ} \mathrm{C}$. The number of permanently-settled cyprids on the bottom and sides of the 
wells was enumerated after 24 and $48 \mathrm{~h}$ of incubation and the percentage settlement was calculated. The permanently-settled cyprids were identified when the antennules were embedded in the cypris permanent adhesive anchored on the surface, with the body showing contractions and subsequent shedding of the carapace.

Static immersion field test in a marina. Six replicates of each polymer were arranged randomly in vertical panels immersed at $50 \mathrm{~cm}$ below the water level, and facing east, at a static immersion test site in Hartlepool Marina, County Durham, UK (54.69 $\mathrm{N}, 1.20^{\circ} \mathrm{W}$ ) from August $30^{\text {th }}$ to October $31^{\text {st }}$, 2012. Temperature and salinity were not monitored, but normally vary over 12$15{ }^{\circ} \mathrm{C}$ and 34-35 psu, respectively, during this period. The fouling coverage was assessed after 1, 2 and 8 weeks of immersion. The biofouling community was divided into four categories: microfouling, weeds, soft- and hard-bodied animals. The percentage of each biofouling category was estimated by visual inspection, relative to the total area of the surface. The samples were not rinsed before estimation of coverage, because this would remove loosely attached materials which are part of the fouling. The sum percentage of these four fouling categories was defined as total percentage of biofouling.

Statistical analysis. Statistical analysis of the biofouling data was carried out using Minitab 15 (barnacle data) or Minitab 16 statistical software. One-way analysis of variance (ANOVA) and Tukey's HSD post-hoc test were performed to determine the differences between treatments. Values were considered significantly different from each other when $p<0.05$. This analysis was applied to protein adsorption, bacterial attachment, spore settlement and adhesion strength, and cyprid settlement assays, as well as the field test results. The percentage data of spore adhesion strength was arcsine transformed prior to statistical analysis.

\section{Results and Discussion}

Polymer preparation and characterization. Cationic PDMAEMA, anionic PSPMA, neutral random PHEMA-co-PEG ${ }_{10}$ MA copolymer, and zwitterionic PSBMA brushes were prepared via SI-ATRP (Figure 1), each with a dry thickness of about $100 \AA$, as determined via ellipsometry. This thickness was achieved by varying the reaction time for each synthesis (Table 1). The variation in reaction time required to achieve $100 \AA$ polymer thickness might be due to differences in inherent reactivity and solvation of the monomers (Ouchi et al. 2011), 
which is strongly influenced by their molecular structure. PHEMA-co-PEG ${ }_{10}$ MA showed the fastest reaction time, as a result of the high solubility of HEMA and PEG ${ }_{10}$ MA monomers in the water-methanol solvent due to the high availability of hydrogen bond acceptor atoms, which facilitates pre-organization of monomers resulting in higher monomer propagation (Jansen et al. 2003). In addition, the larger monomer size of $\mathrm{PEG}_{10} \mathrm{MA}$ might also contribute to achieving $100 \AA \AA$ of PHEMA-co-PEG ${ }_{10}$ MA layer thickness faster than for the smaller monomers.

The ellipsometric thickness of the initiator SAM is $22 \AA$, consistent with near-upright molecules, though the positions of the asymmetric and symmetric C-H stretching modes at 2923 and $2852 \mathrm{~cm}^{-1}$, respectively, indicate a layer with considerable disorder. Hence, the initiator SAM forms a dense, but not crystalline, monolayer. The chemical composition of the grafted polymers was evaluated by FT-IRAS (Figure 2). The ester carbonyl $(\mathrm{C}=\mathrm{O})$ stretching around $1731-1737 \mathrm{~cm}^{-1}$ is prominent in all polymers, and the increase in intensity of this band, relative that of the initiator SAM, reflects the addition of monomers through successful methacrylate polymerization. This absorption is weak in the initiator SAM, because of its transition dipole moment being parallel to the metal substrate, in which case the surface selection rule dictates that the intensity is weak. The C-O ester stretching near $1245 \mathrm{~cm}^{-1}$ is also present in the spectra, but overlapping with other bands in some cases. We also note the overall lack of bands near the $1640 \mathrm{~cm}^{-1}$ absorbance of methacrylate $\mathrm{C}=\mathrm{C}$ bonds, which would have indicated the presence of free monomers in the films. All spectra have in common several C-H vibrations, whose exact locations depend on the type of polymer. The dominating $\mathrm{C}-\mathrm{H}$ modes are stretching in the range 2800-3000 cm-1, deformation modes near 1450 and $1480 \mathrm{~cm}^{-1}$ (scissoring), 1250 and $1270 \mathrm{~cm}^{-}$ ${ }^{1}$ (twisting). The presence of the HEMA and PEG ${ }_{10}$ MA segments is confirmed by several features in the spectrum: the broad band from hydrogen-bonded O-H-stretching over 3100-3600 $\mathrm{cm}^{-1}$, which is absent from the spectrum of the initiator SAM; and by the C-O-C skeletal stretching vibration in the PEG chains at $1158 \mathrm{~cm}^{-1}$ (Lee et al. 2009). The asymmetric and symmetric $\mathrm{CH}_{2}$ stretching modes of PEG were observed as broad bands at 2942 and $2876 \mathrm{~cm}^{-}$ 1, respectively. In PDMAEMA, a tertiary amine C-H stretching is present at $2772 \mathrm{~cm}^{-1}$, and peaks at 1154 and 1193 are tentatively assigned C-N stretching and contributions from C-H deformations in the tertiary dimethyl groups. The presence of sulfonate $\left(\mathrm{SO}_{3}{ }^{-}\right)$in the SPMA and SBMA samples is confirmed by a strong symmetric $S=0$ stretching peak observed at 1035 and $1039 \mathrm{~cm}^{-1}$, respectively. In PSPMA, the asymmetric S=O absorption, which is expected near $1200 \mathrm{~cm}^{-1}$, is most likely split (and partially overlapping the C-O ester stretching) as a result of asymmetric binding of counterions to the sulfonate (Ramstedt et al. 2007), while in PSBMA this remains as a single band centered at $1214 \mathrm{~cm}^{-1}$, with shoulders most likely from 
C-O ester stretching, and amine C-N stretching on the low-frequency side. Taken together, these results show that PHEMA-co-PEG ${ }_{10}$ MA, PDMAEMA, PSPMA and PSBMA were successfully prepared on initiator SAM-coated gold substrates. The root mean square (RMS) surface roughness values of the dry polymer films, as determined by AFM on the PHEMA-CoPEG $_{10}$ MA, PDMAEMA, PSPMA and PSBMA films were 0.64, 0.56, 0.79 and $0.81 \mathrm{~nm}$, respectively (Figure 3). The small and similar RMS values indicate that all polymers were prepared in uniform and smooth layers.

Wettability and surface energy. Sessile droplets of deionized water on PHEMA-co-PEG ${ }_{10} \mathrm{MA}$, PSPMA and PSBMA in air have lower contact angles than on PDMAEMA, which indicates that these three polymers are more hydrophilic than PDMAEMA (Table 1). This result was also confirmed by the determination of surface free energies of the hydrated polymers, where the surface energy of PDMAEMA was found to be lower than those of the three other polymers. This indicates a stronger interaction of PHEMA-Co-PEG ${ }_{10}$ MA, PSPMA and PSBMA with water molecules than for PDMAEMA in a pH-neutral environment.

In general, measurements of wettability and the determination of surface energy are affected by both surface topography (Quere 2008, Spori et al. 2008) and surface chemistry (Meuler et al. 2011, Schilp et al. 2007). Since the AFM measurements in Figure 3 show that these four polymer surfaces have small variations in RMS roughness, we assume that surface chemistry plays the most important role in determining wettabilities and surface energies. Strong hydrophilicity and high surface energy of PHEMA-Co-PEG ${ }_{10}$ MA result from the strong dipoles formed by the PEG ether units, which effectively bind water molecules to the PEG chain. The strong hydrophilic character of PSPMA results from solvation of sulfonate ions, giving higher surface hydration. The zwitterionic PSBMA, like several other zwitterionic materials, has been reported to be more strongly hydrated than many uncharged hydrophilic polymers via electrostatically-induced hydration (Chen et al. 2010). For PDMAEMA, the higher sessile water droplet contact angle (in air) and lower surface energy might be a result of weaker ion-dipole interactions between PDMAEMA and water molecules due to only partial ionization of the ammonium group, and possibly also of the presence of hydrophobic segments on this polymer. PDMAEMA is a weak polycation, with pKa near 8 . This means that less than half of the dimethyl amino groups are charged at $\mathrm{pH}$ 8.2. The wettability data presented in Table 1 shows that PDMAEMA is more hydrophobic than the other polymers, but the difference does not suggest that the materials is uncharged, in which case the hydrophobic nature of the 
hydrocarbons would be more pronounced. A more thorough investigation of the $\mathrm{pH}$ dependence shows that at high pH, of PDMAEMA is uncharged, and collapsed, but both our own unpublished investigations (Yandi et al. In preparation) and published data (Lee et al. 2011) demonstrate that this is not the case at the $\mathrm{pH}$ of ASW, but that PDMAEMA have approximately $10 \%$ of the amino residues protonated at a $\mathrm{pH}$ of 8.2 . Hence, we here refer to PDMAEMA as 'cationic', although the polymer itself is nominally neutral.

While hydrophilicity and surface hydration are important for antifouling properties, many other factors such as surface chemistry, surface topography, polymer conformation, chain packing density and electrostatic interactions contribute to fouling resistance, and must also be considered. As an example, we recently demonstrated the importance of surface hydration and polymer viscoelasticity for the antifouling properties of PHEMA-co-PEG 10 MA films of varying thicknesses (Yandi et al. 2014).

Captive air bubbles were used to measure contact angles in both deionized water and in ASW (pH 8.2 and total salt concentration about 0.6 M). The captive-bubble contact angles in ASW were lower than in deionized water for PHEMA-co-PEG ${ }_{10}$ MA, PDMAEMA, and PSPMA, with the largest differences for PDMAEMA and PSPMA, see Table 1. This decrease in contact angles is probably a result of partial dehydration of the polymer brushes caused by electrostatic screening of charges, leading to weakening of the hydration shells. In accord with this, the change was smallest for the nominally uncharged PHEMA-co-PEG ${ }_{10}$ MA sample. In contrast, the air bubble contact angle in ASW increased on PSBMA, compared to the contact angle in deionized water. This increase might be a result of the unique antipolyelectrolyte behavior of PSBMA, i.e., chain expansion due to a viscosity increase in the presence of salt ions, as has been reported previously (Chang et al. 2009, Chang et al. 2010). It is useful to compare the contact angles obtained with sessile droplets in air with those obtained underwater on the hydrated films. The contact angles obtained in air can be compared directly with the captive-bubble contact angles if the latter are subtracted from 180 degrees, to take into account that the geometries for measuring the angles are reversed. The corresponding angles thus obtained underwater are 20-30 degrees lower than those obtained in air. This demonstrates that the brushes are strongly hydrated. Moreover, the difference is greater than that between the angles obtained in deionized water and ASW, showing that while ASW has a dehydrating effect on the brushes, it does not induce them to collapse, or to adopt the structure of the dry films. 


\section{Fouling assays}

Protein adsorption. Protein adsorption on surfaces is an essential aspect of the biofouling process since fouling organisms often secrete temporary or permanent adhesives, which frequently consist of proteins and glycoproteins. Adsorbed proteins might also act to condition a surface, to influence further or subsequent adhesion or attachment of fouling organisms. We used three different proteins: fibrinogen (a frequently used model for a 'sticky' protein), lysozyme (net positively charged at $\mathrm{pH}$ 7.4) and pepsin (net negatively charged at $\mathrm{pH}$ 7.4). As shown in Figure 4, adsorption after $1 \mathrm{~h}$ static incubation was overall low onto PHEMA-co$\mathrm{PEG}_{10} \mathrm{MA}$ and PSBMA, in agreement with previous results on the protein resistance of these materials (Larsson et al. 2007, Yandi et al. 2014). The highest adsorption was obtained in the systems where surface and protein had opposite net charge, i.e. for PDMAEMA-pepsin (56.2 \pm $1.2 \AA)$ and PSPMA-lysozyme (42 $\pm 1.6 \AA$ ), as it would be expected from electrostatic considerations. Similarly, the pattern was opposite for adsorption of lysozyme and pepsin on PDMAEMA and PSPMA, respectively, presumably due to repulsive electrostatic interactions. Beyond these rather unsurprising observations, we found that the adsorption of fibrinogen was significantly greater than zero (ANOVA, $p<0.05$ ) on all polymers, including also the neutral PHEMA-co-PEG ${ }_{10}$ MA, with the exception of the zwitterionic PSBMA. Fibrinogen is known to attach indiscriminately on many different types of surfaces. One reason for this is the amphoteric properties of the protein, with domains of different net charge, even though the whole fibrinogen molecule is net negatively charged at pH 7.4. (Wasilewska \& Adamczyk 2011). Thus, the adsorption of fibrinogen on PDMAEMA, and to some extent also on PSPMA, can be associated with attractive electrostatic interactions (though this does not explain why adsorption is higher on the nominally neutral PHEMA-co-PEG ${ }_{10}$ MA than on the zwitterionic PSBMA). Early studies on the adsorption of fibrinogen on various polyelectrolyte surfaces also demonstrated high adsorption (from concentrations $>0.5 \mathrm{mg} / \mathrm{mL}$ ) on those which have bulk ionexchange capacities of +0.8 meq g$^{-1}$ (Schmitt et al. 1983). The presence of deprotonated and hydrophobic segments in PDMAEMA at pH 7.4 might also contribute to a higher adsorption via hydrophobic interactions.

Bacterial attachment. The marine bacterium Cobetia marina was used as a model organism to study the interactions of marine bacteria with the polymers. Bacterial densities (after $1 \mathrm{~h}$ incubation on a rotary shaker) determined from epifluorescence images are presented in Figure 5 and showed that cells attached abundantly onto the cationic PDMAEMA (7539 \pm 1564 
cells $/ \mathrm{mm}^{2}$ ). Numbers of attached bacterial cells to PHEMA-co-PEG ${ }_{10}$ MA (203 \pm 98 cells $\left./ \mathrm{mm}^{2}\right)$, PSPMA (206 \pm 112 cells $\left./ \mathrm{mm}^{2}\right)$ and PSBMA (103 \pm 47 cells $\left./ \mathrm{mm}^{2}\right)$ were significantly lower compared to DMAEMA (ANOVA, $p<0.05$ ), and not significantly distinguishable from each other (ANOVA, Tukey's pairwise comparison test, $p<0.05$ ), and in agreement with previous studies on the attachment of cells of $C$. marina on PEG hydrogels and EG 6 SAMs (Ekblad et al. 2008, Ista et al. 1996). Higher attachment of $C$. marina on the cationic PDMAEMA is very likely caused by attractive electrostatic interaction with cells of $C$. marina, which was reported by Mitik-Dineva et al (Mitik-Dineva et al. 2009) to have a surface zeta potential of $-32 \mathrm{mV}$. Considering this negative charge, which is also greater in magnitude than that of spores of $U$. linza (zeta potential $-19 \mathrm{mV}$ ) where PDMAEMA showed anti-algal activity (see below), we anticipate that antibacterial properties of PDMAEMA might be expressed, since this has been demonstrated in previous studies (Karamdoust et al. 2012). However, in the present study, antibacterial activity of PDMAEMA towards C. marina was not immediately apparent, and was not further investigated either.

Although no comprehensive studies on the influence of polymer charge on the attachment of cells of $C$. marina have been reported yet, Pranzetti et al. (Pranzetti et al. 2012) demonstrated higher attachment of cells of C. marina (1 h exposure) on positively charged amine-terminated SAMs than on neutral (methyl-, EG6- or hydroxyl-terminated) SAMs, which is in accordance with our current results. It has also been reported (Ista et al. 1996, Ista et al. 1999) that cells of $C$. marina have a higher affinity for hydrophobic surfaces ( 2 h exposure). As described above, the pH of ASW is 8.2, where PDMAEMA has weaker net positive charge than at 7.4 due to reduced protonation of the ammonium, rendering the dimethylammonium segments considerably less polar, and the presence of more hydrophobic segments of PDMAEMA at this $\mathrm{pH}$ might also contribute to the high attachment via hydrophobic interactions.

Settlement and attachment strength of Ulva zoospores. Figure 6 shows the settlement densities of zoospores on the four polymers, as observed by epifluorescence microscopy (after 45 min exposure under static conditions). The spore density differed with the surface type (ANOVA, $p<0.05$ ), and settlement on each surface is significantly different from that on every other, according to the Tukey's pairwise comparison test $(p<0.05)$. The highest number of spores was found on the cationic PDMAEMA (1276 \pm 193 spores $\left./ \mathrm{mm}^{2}\right)$. However, the adhesion strength of the attached spores was relatively weak, as indicated by a high percentage of spore removal (near $80 \%$ ) after exposure to a wall shear stress of $52 \mathrm{~Pa}$. The high settlement is likely 
to be due to the higher hydrophobicity and the associated lower surface hydration of PDMAEMA, and also electrostatic interaction between the positively charged polymer and the negatively charged cells. This is in line with previous studies which have demonstrated the high affinity of zoospores to positively charged surfaces (Ederth et al. 2008, Ederth et al. 2009, Maleshlijski et al. , Rosenhahn et al. 2009, Vater et al. 2015). Although little settlement of spores was observed on the anionic PSPMA (180 \pm 27 spores $\left./ \mathrm{mm}^{2}\right)$ and zwitterionic PSBMA $\left(60 \pm 9\right.$ spores $\left./ \mathrm{mm}^{2}\right)$, it is clear that spores were also weakly attached on these brushes. The presence of negative charges on PSPMA might induce repulsion of spores of $U$. linza, which have a net negative charge (Rosenhahn et al. 2009). The settlement of spores on neutral PHEMA-co-PEG ${ }_{10} \mathrm{MA}\left(13 \pm 3\right.$ spores $/ \mathrm{mm}^{2}$ ) was the lowest (ANOVA, Tukey's pairwise comparison, $p<0.05)$. Regarding the adhesion strength of spores, the weakest adhesion strength was found on PSPMA, which is indicated by the high percent removal (88\%). This adhesion strength is significantly weaker compared to the others (ANOVA, Tukey's test, $p<0.05$ ). The adhesion strength of spores on PSBMA does not differ significantly from that on PDMAEMA (ANOVA, Tukey's test, $p>0.05$ ), but is significantly lower than that on PHEMA-Co-PEG ${ }_{10}$ MA (ANOVA, Tukey's test, $p<0.05$ ). However, since the numbers of settled spores are very small on all but the PDMAEMA samples, the latter differences must be taken with some caution.

Settlement characteristics of U. linza spores on cationic PDMAEMA. Beside a high settlement density, we also found qualitative difference in spores attached on the cationic PDMAEMA. For example, anomalous 'settlement' of spores in the form of pear-shaped spores with unretracted flagella (Figure 7), disrupted cells as well as detached flagella were also observed on this surface. Close inspection revealed that about 20 percent of attached spores showed anomalous settlement (ie pseudosettled spores), 20 percent were disrupted (ie damaged) cells and the remaining 60 percent were normal settled cells (ie rounded spores with an intact plasma membrane). The presence of net positive charge in PDMAEMA leads to favorable attractive electrostatic interaction with the negatively charged spore surface membrane. Instead of initially probing and then attaching to the surface on its apical papilla, as is the case for normal settlement, the spore body appeared to have attached directly onto the cationic PDMAEMA, mediated by attractive electrostatic and hydrophobic interactions and observed as pear-shaped cells that were morphologically identical to motile spores. This anomalous settlement behavior of spores has been observed in our previous study on the settlement of spores on cationic oligopeptide SAMs (Ederth et al. 2008, Ederth et al. 2009). Detached flagella on the PDMAEMA surface might indicate entrapment of flagella via attractive electrostatic and 
hydrophobic interactions during surface exploration since the plasma membrane surrounds the flagella as well as the spore body. A feature of the surface exploration by zoospores is a phase of rapid spinning, and this might contribute to detachment of the flagella if the latter stick to the surface during this phase. The disrupted spores might also be correlated to the antimicrobial activity of PDMAEMA (Karamdoust et al. 2012). It is conceivable that strong interaction between anionic lipopolysaccharides on the spore membrane and the cationic PDMAEMA brush could lead to the disruption of the cell surface membrane via penetration of the membrane by the polymer. Details of the interactions of $U$. linza zoospores with cationic PDMAEMA surfaces, and their potential anti-algal function, will be discussed in a separate publication.

Barnacle cyprid settlement. The settlement of cyprids from two different barnacle species, Balanus amphitrite and B. improvisus, was also studied (at 24 and $48 \mathrm{~h}$ after incubation under static conditions). Figure 8 shows that after 48 h, cyprids from these two species follow the same pattern in that they settled to a higher degree on the charged polymers PDMAEMA (20.35 $\pm 4 \%$ for B. amphitrite and $28.06 \pm 6 \%$ for B. improvisus) and anionic PSPMA (40.35 $\pm 4 \%$ for B. amphitrite and $51.37 \pm 3 \%$ for $B$. improvisus). Contrary, lower settlement was observed on zwitterionic PSBMA (3.9 $\pm 2 \%$ for B. amphitrite and $14.72 \pm 4 \%$ for B. improvisus) and on neutral PHEMA-Co-PEG ${ }_{10}$ MA (5.6 $\pm 2 \%$ for B. amphitrite and $13.37 \pm 5 \%$ for $B$. improvisus). Settlement data differed significantly between surfaces (B. amphitrite $p<0.05, F$ $=22.96$ and $B$. improvisus $p<0.05, F=15.72$ ) at 95\% confidence (ANOVA, Tukey's method). Settlement of $B$. improvisus on the cationic PDMAEMA surfaces was high, following the trend of B. amphitrite, but not significantly different from PSBMA and PHEMA-PEGMA surfaces (Tukey's pairwise comparison of means) (see Figure 8). The settlement assay results are in good agreement with previous studies (Di Fino et al. 2014, Petrone et al. 2011) using various charged SAMs, in two respects: 1) settlement was highest on the anionic surface, and 2) the overall pattern of settlement for both species was very similar. Low settlement of cyprids on the PHEMA-co-PEG ${ }_{10}$ MA surface is also in accordance with results obtained by Aldred et al. (2011) who observed fewer footprints of cyprid temporary adhesive deposited during searching behavior by Semibalanus balanoides on a $\mathrm{PEG}_{10} \mathrm{MA} / \mathrm{HEMA}$ hydrogel compared to a range of model SAMs. There is good evidence to suggest that cyprid temporary adhesive contains a glycoprotein termed the settlement-inducing protein complex (SIPC). SIPC has recently been found to behave as a sticky protein with binding characteristics similar to fibrinogen (Petrone et al. 2014). In this regard, it is interesting to note that the degree of binding of fibrinogen to surfaces used in the present study is broadly similar to the pattern of cyprid settlement obtained 
on the same surfaces; a result to be expected if the SIPC is important to effecting temporary adhesion.

Field tests. The biofouling after one week of immersion in a marine environment was dominated by microfouling (ie slime) whatever the surface chemistry (Figure 9). Contrary to the bioassays carried out in the laboratory using model fouling organisms, the biofouling on the cationic PDMAEMA was significantly lower (ANOVA, Tukey's test, $p<0.05$ ) than on the zwitterionic PSBMA, and did not differ significantly (ANOVA, Tukey's test, $p>0.05$ ) from the anionic PSPMA or the neutral PHEMA-Co-PEG ${ }_{10}$ MA after one week of immersion in a marina. Furthermore, the total biofouling on the PSPMA was significantly lower (ANOVA, Tukey's test, $p<0.05$ ) than on the zwitterionic PSBMA and the neutral PHEMA-Co-PEG ${ }_{10}$ MA. Although the complexity of the fouling conditions in the field test situation prevents a meaningful interpretation of these observations in terms of molecular properties of the surfaces, they are still interesting since both, neutral and zwitterionic surfaces, typically perform better than the net charged polymers in the laboratory assays.

After two weeks of immersion, the biofouling was still dominated by slime. The settlement of microfouling organisms on the neutral PHEMA-Co-PEG ${ }_{10}$ MA was lower (ANOVA, Tukey's test, $p<0.05$ ) than on any of the other three chemistries (which were indistinguishable), and the total fouling was reduced compared to that after one week of immersion. This might indicate weak or temporary attachment of microfouling organisms on this particular polymer. Similar results have been obtained in laboratory assays on ethylene glycol-rich surfaces where settlement of the diatom Navicula perminuta was found to be low (Schilp et al. 2009). All samples were fully covered by biofouling (weeds and to a lesser extent microfouling) after eight weeks' immersion, and they did not differ significantly between each other (ANOVA, $p>0.05$ ), possibly due to chemical or mechanical instability of the samples under the influence of temperature, water currents and salinity. It is also important to note that surfaces are rapidly (hours) 'conditioned' by adsorption of macromolecules on immersion, a process that may change the surface properties (Thome et al. 2014). Furthermore, the adhesion and settlement of organisms in marine environments is a dynamic and complex process since many parameters influence the pattern of adhesion and settlement (Hellio \& Yebra 2009), and which is also dependent on local variations in fouling pressure. Larger biodiversity and adhesion mechanism differences also lead to complications in the detailed interpretation of field tests. 


\section{Conclusions}

In general, the tested model fouling organisms have a higher tendency to attach and settle on charged polymer surfaces than onto neutral and zwitterionic surfaces under controlled laboratory conditions, in agreement with previous knowledge, suggesting that net charge is undesirable in antifouling materials. However, many nominally neutral materials acquire surface charge upon immersion in saline media, and a number of observations were made that are of general relevance, and which should be of interest to future studies of marine bioadhesion, and also for the development of antifouling coatings. The antifouling activity of anionic PSPMA against the marine bacterium $C$. marina is on a par with the neutral and zwitterionic polymers. Settlement of zoospores of $U$. linza on PSPMA was very low, and spore adhesion strength to PSPMA was the lowest among the tested polymers. Our results also confirm recent observations obtained on model SAMs showing that the settlement preferences of the two barnacle species $B$. amphitrite and $B$. improvisus are similar, and that low cyprid settlement on PSPMA and PHEMA-Co-PEG ${ }_{10}$ MA conformed to expectations based on prior studies. Despite high settlement of algal spores on cationic PDMAEMA, this surface shows potential for the development of non-leaching contact-active anti-algal surfaces, due to its inherent ability to kill spores upon contact. Field immersion tests in a marina even showed that both PSPMA and PDMAEMA had better antifouling properties at the end of 1 week of immersion than PHEMAco-PEG ${ }_{10} \mathrm{MA}$ and PSBMA, which are both well known for their superior antifouling properties. The reason for the opposite results of the field tests and the laboratory assays in this respect is not known, but point to the relevance of further studies of the physicochemical properties and interactions with fouling species of both PDMAEMA and PSPMA, and with charged surfaces in general.

\section{Acknowledgements}

We thank Dr. John Finlay for assistance with acquiring the images of normal and pseudosettled spores of Ulva linza. This study has received funding from the European Community's Seventh Framework Program FP7/2007-2013 under Grant Agreement number [237997] (SEACOAT). TE acknowledges financial support from the Swedish Government Strategic Research Area in Materials Science on Functional Materials at Linköping University (Faculty Grant SFO-MatLiU \#2009-00971). 


\section{Tables}

Table 1. Ellipsometric thicknesses, SI-ATRP polymerization times, static contact angles (CA), and surface free energies of the used polymers (DI = deionized water).

\begin{tabular}{|c|c|c|c|c|c|c|c|c|}
\hline \multirow[b]{2}{*}{ Sample } & \multirow[b]{2}{*}{ Туре } & \multirow[b]{2}{*}{$\begin{array}{l}\text { Film thickness } \\
(\AA)\end{array}$} & \multirow[b]{2}{*}{$\begin{array}{c}\text { Polymerization } \\
\text { time } \\
(\mathrm{min}) \\
\end{array}$} & \multirow[b]{2}{*}{$\begin{array}{c}\text { Sessile droplet } \\
\text { CAs in air } \\
\text { (deg) }\end{array}$} & \multicolumn{3}{|c|}{ Captive-bubble contact angles } & \multirow[b]{2}{*}{$\begin{array}{c}\text { Surface energy } \\
\text { in DI } \\
\left(\mathrm{mJ} / \mathrm{m}^{2}\right) \\
\end{array}$} \\
\hline & & & & & $\begin{array}{c}\text { n-octane } \\
\text { in DI } \\
\text { (deg) }\end{array}$ & $\begin{array}{c}\text { Air in DI, } \\
\text { pH } 7.0 \\
\text { (deg) }\end{array}$ & $\begin{array}{c}\text { Air in ASW, } \\
\text { pH } 8.2 \\
\text { (deg) }\end{array}$ & \\
\hline PHEMA-CO-PEG ${ }_{10} \mathrm{MA}$ & Neutral & $101 \pm 3$ & 5 & $64 \pm 2$ & $139 \pm 1$ & $140 \pm 1$ & $135 \pm 2$ & 56 \\
\hline PDMAEMA & Cationic & $105 \pm 2$ & 63 & $74 \pm 2$ & $121 \pm 1$ & $134 \pm 1$ & $121 \pm 1$ & 53 \\
\hline PSPMA & Anionic & $97 \pm 1$ & 35 & $62 \pm 1$ & $150 \pm 2$ & $148 \pm 2$ & $140 \pm 1$ & 62 \\
\hline PSBMA & Zwitterionic & $95 \pm 2$ & 20 & $61 \pm 2$ & $160 \pm 3$ & $146 \pm 1$ & $151 \pm 1$ & 61 \\
\hline
\end{tabular}


Figures
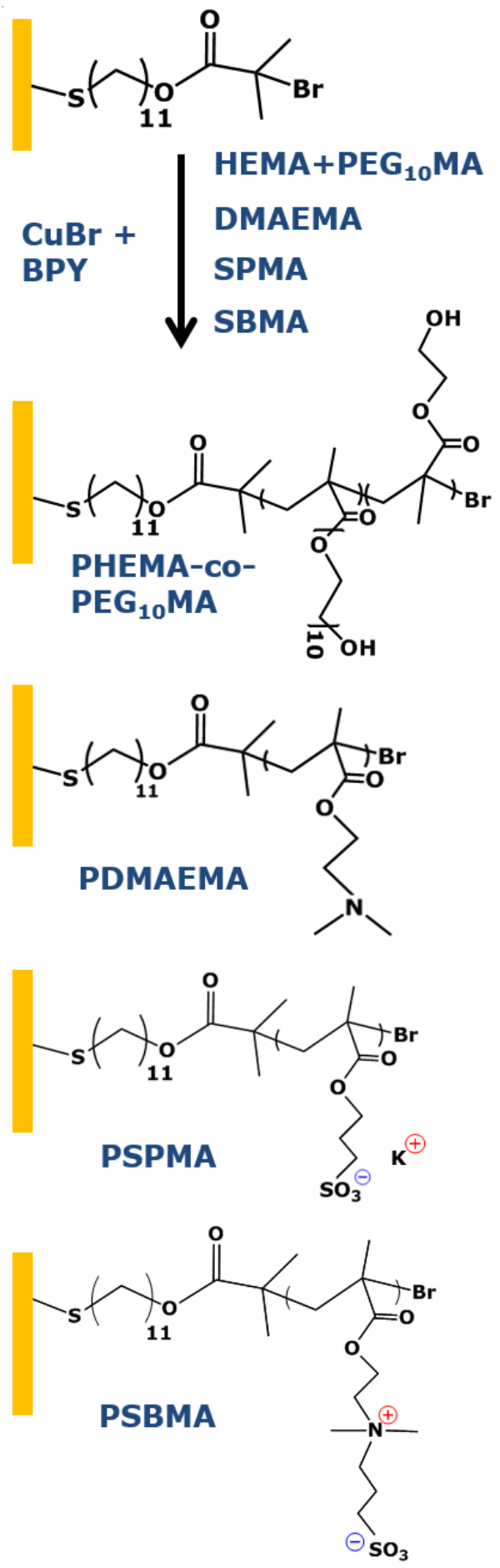

Figure 1. Preparation of polymers (cationic PDMAEMA, anionic PSPMA, neutral random PHEMA-co-PEG ${ }_{10}$ MA copolymer, and zwitterionic PSBMA) onto gold surfaces with an initiator SAM (top) via surface-initiated atom transfer radical polymerization (SI-ATRP). 

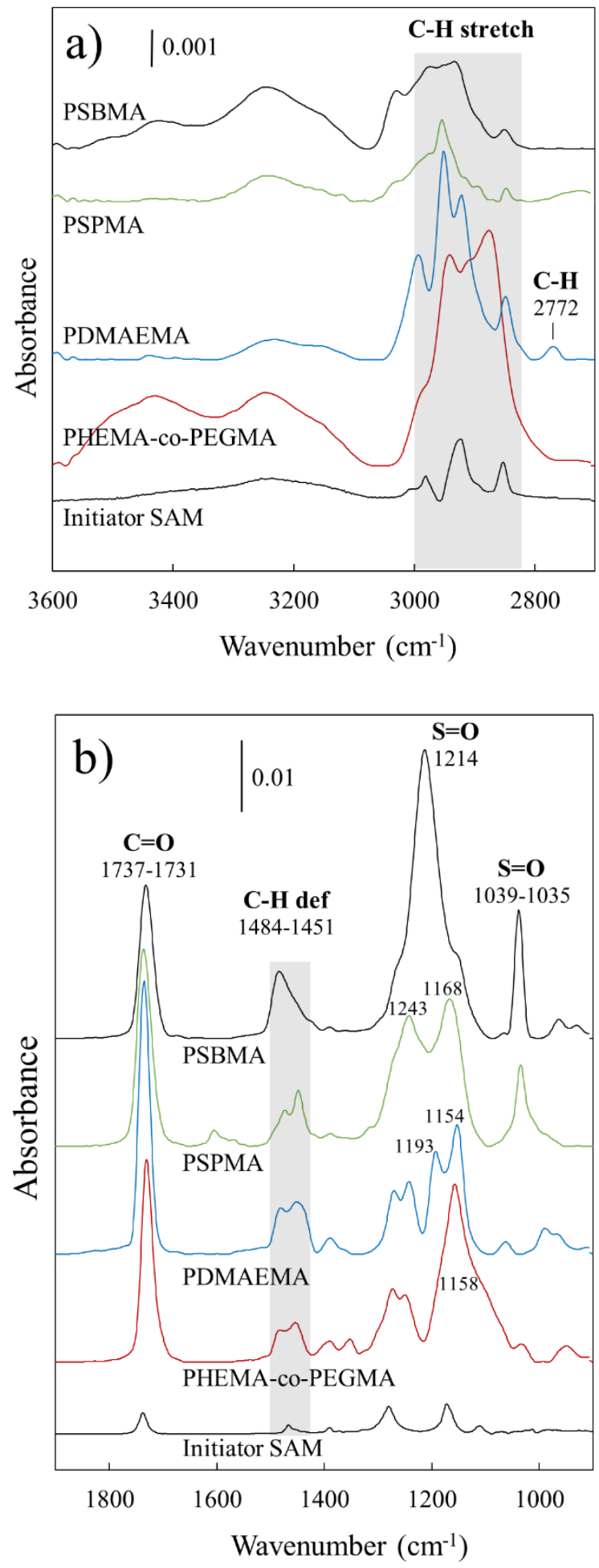

Figure 2. Infrared reflection-absorption spectra of the used polymers and also of the initiator SAM, for comparison. a) The $\mathrm{O}-\mathrm{H}$ and $\mathrm{C}-\mathrm{H}$ stretching regions. b) The fingerprint region. See text for details about peak assignments. 

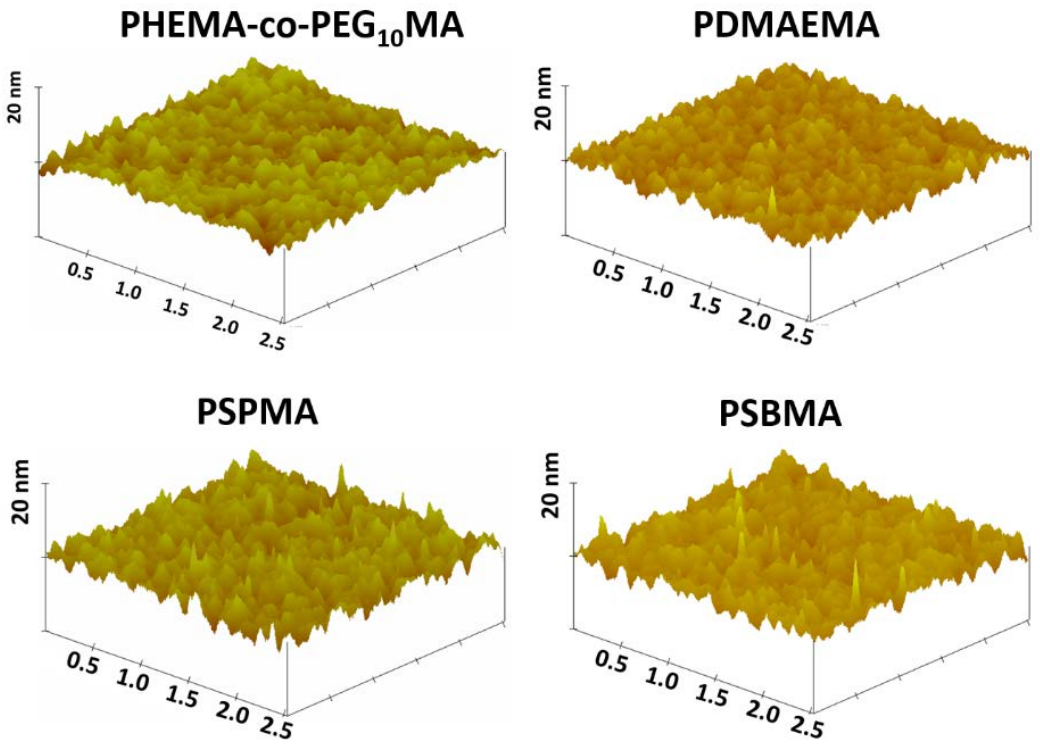

Figure 3. AFM images of the dry polymer films, measured in tapping mode in air. Each image corresponds to an area of $2.5 \times 2.5 \mu \mathrm{m}^{2}$. 


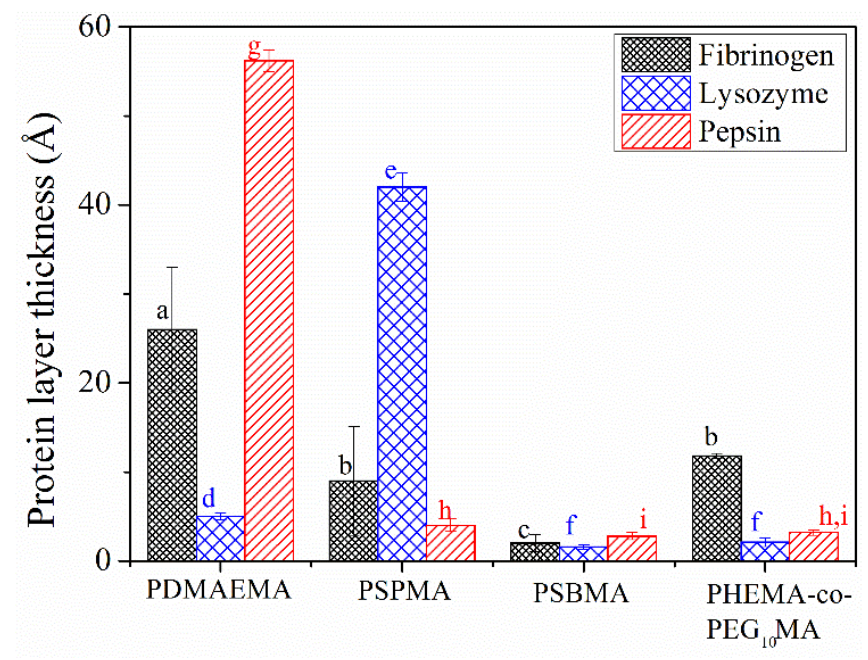

Figure 4. Adsorption of fibrinogen, lysozyme (cationic) and pepsin (anionic) on cationic PDMAEMA, anionic PSPMA, zwitterionic PSBMA and neutral PHEMA-coPEG ${ }_{10} \mathrm{MA}$, after $1 \mathrm{~h}$ incubation in $0.4 \mathrm{mg} / \mathrm{mL}$ protein solutions in PBS at $\mathrm{pH}$ 7.4. The error bars represent the Standard Deviation (SD) from six measurements on each sample. Letters (a-i) indicate data points that do not differ significantly from each other at $p<0.05$. 


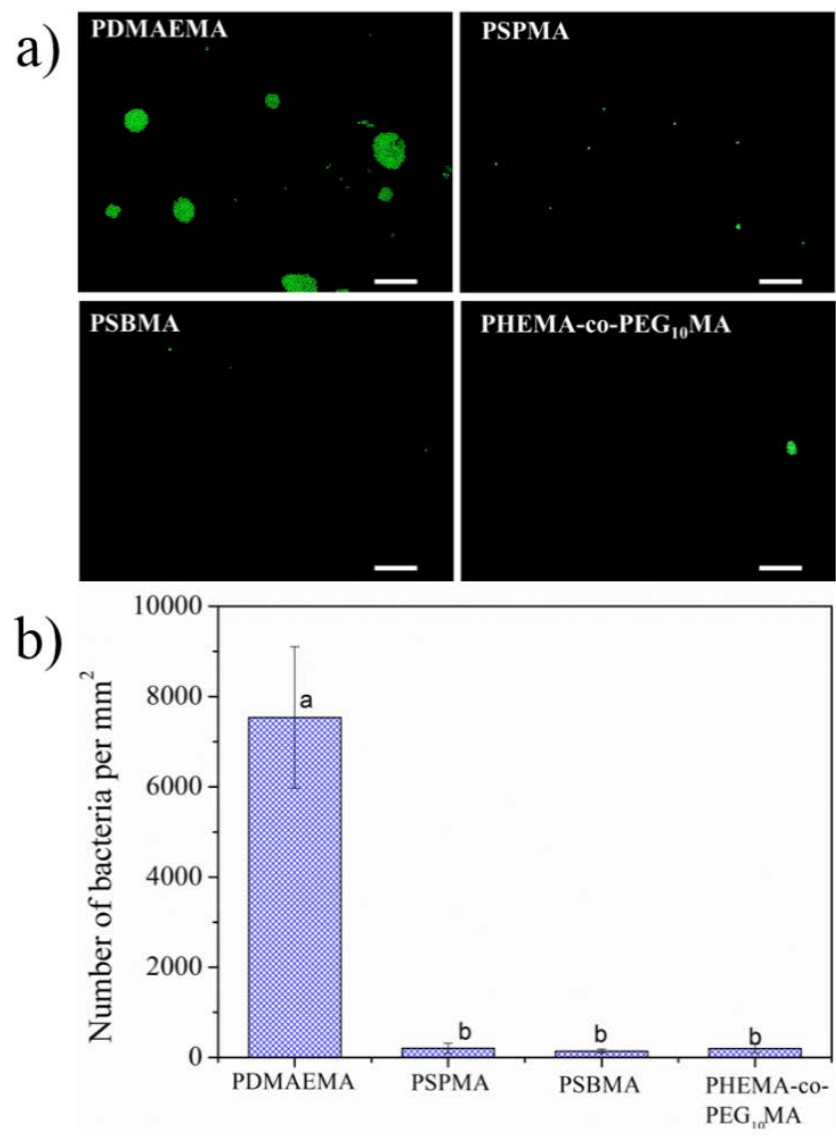

Figure 5. Epifluorescence images (a) and the corresponding number densities (b) of the marine bacterium Cobetia marina attached to cationic PDMAEMA, anionic PSPMA, zwitterionic PSBMA and neutral PHEMA-Co-PEG ${ }_{10}$ MA. Scale bars in (a) are $40 \mu \mathrm{m}$. Error bars in (b) represent $\pm 2 \times$ Standard Error (SE) from 30 measurement spots on each sample. Letters (a-b) indicate data points that do not differ significantly from each other at $p<0.05$. 

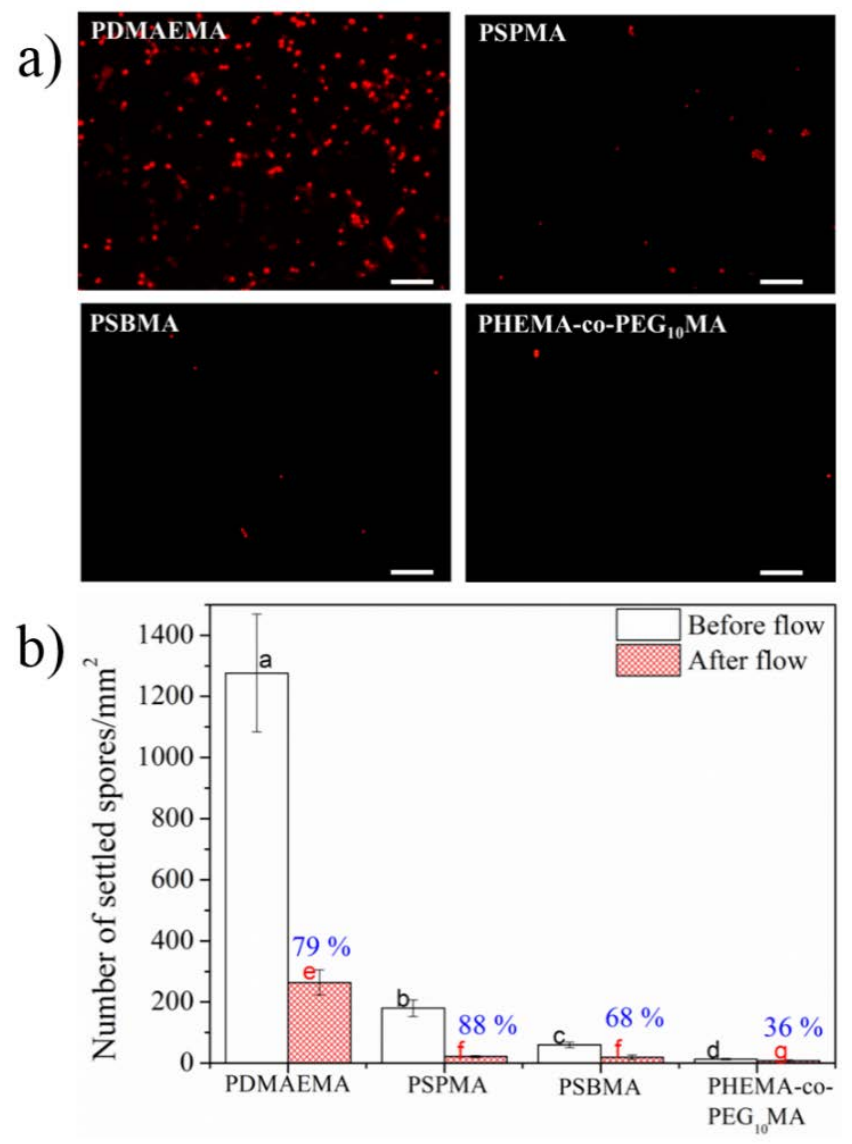

Figure 6. Epifluorescence images (a) and the corresponding number (b) of attached zoospores of the marine alga Ulva linza on cationic PDMAEMA, anionic PSPMA, zwitterionic PSBMA and neutral PHEMA-co-PEG10MA prior to (white) and after (hatched) exposure to a wall shear stress of $52 \mathrm{~Pa}$. Scale bars in figure 6a are $20 \mu \mathrm{m}$. Percentages in blue represent the percent removal of spores after exposure to $52 \mathrm{~Pa}$ shear stress calculated from arcsine-transformed data with $95 \%$ confidence limit. Error bars represent $\pm 2 \times$ SE calculated from arcsine-transformed data with $95 \%$ confidence limits. Letters indicate data points that do not differ significantly from each other at $p$ $<0.05$. 
Figure 7. (a) A normally settled and (b) a pseudosettled spore of Ulva linza, as observed on the cationic PDMAEMA surface. Scale bar $=5 \mu \mathrm{m}$. 


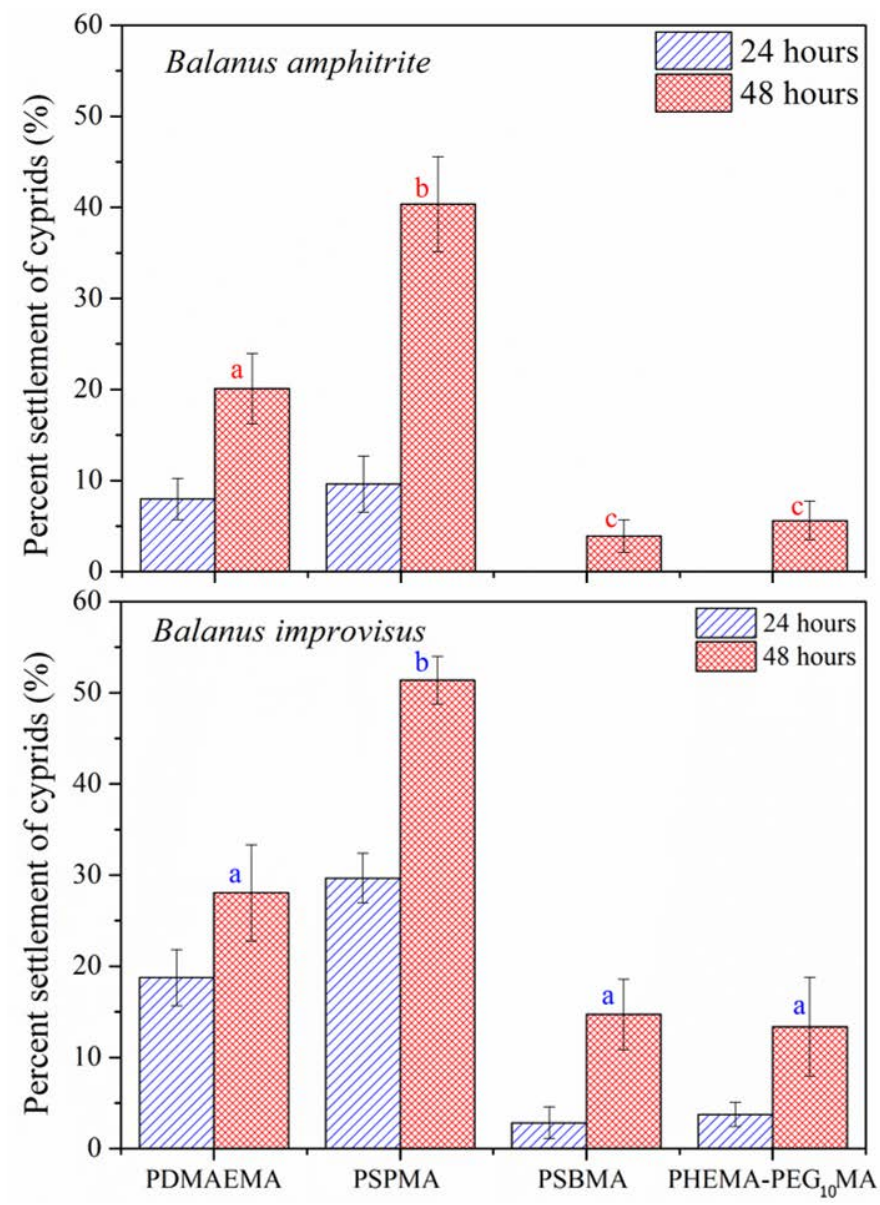

Figure 8. Percent settlement of cyprids of Balanus amphitrite and Balanus improvisus on cationic PDMAEMA, anionic PSPMA, zwitterionic PSBMA and neutral PHEMAco-PEG ${ }_{10}$ MA observed after 24 and 48 hours of incubation. Error bars represent $\% \pm$ SE. No significant differences were detected for settlement on the different surfaces at 24 hours. Tukey pairwise comparisons are presented. Means that do not share a letter are significantly different. 


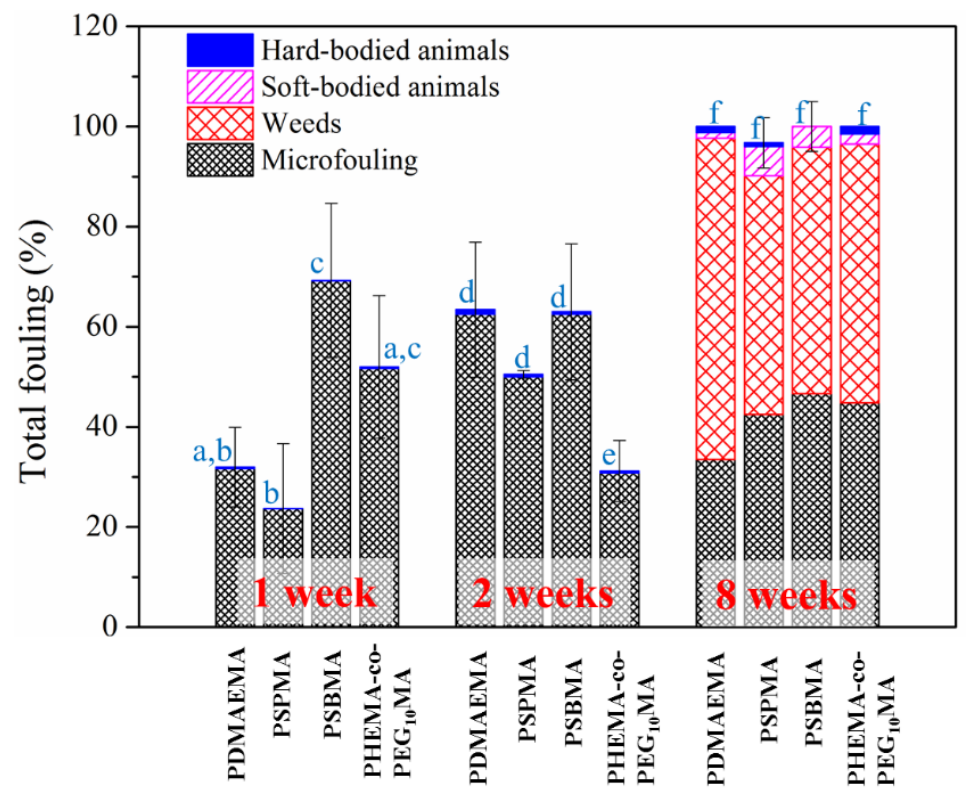

Figure 9. Percent coverage of total biofouling observed after 1, 2 and 8 weeks of immersion in seawater at the depth 0.5 meter below sea level on cationic PDMAEMA, anionic PSPMA, zwitterionic PSBMA and neutral PHEMA-co-PEG ${ }_{10}$ MA. Error bars represent standard deviations of the total biofouling from six replicates of each sample. Letters indicate data points that do not differ significantly from each other at $p<0.05$. 


\section{References}

Aldred N, Ekblad T, Andersson O, Liedberg B, Clare AS. 2011. Real-time quantification of microscale bioadhesion events in situ using imaging surface plasmon resonance (iSPR). ACS Appl Mater Inter. 3:2085-2091.

ASTM. 2013. Standard D1141 - 98(2013), "Standard Practice for the Preparation of Substitute Ocean Water". In: West Conshohocken, PA: ASTM International.

Atalah J, Bennett H, Hopkins GA, Forrest BM. 2013. Evaluation of the sea anemone Anthothoe albocincta as an augmentative biocontrol agent for biofouling on artificial structures. Biofouling. 29:559-571.

Bereschenko LA, Stams AJM, Euverink GJW, van Loosdrecht MCM. 2010. Biofilm Formation on Reverse Osmosis Membranes Is Initiated and Dominated by Sphingomonas spp. Appl Environ Microb. 76:2623-2632.

Bhadury P, Wright PC. 2004. Exploitation of marine algae: biogenic compounds for potential antifouling applications. Planta. 219:561-578.

Callow JA, Callow ME. 2011. Trends in the development of environmentally friendly fouling-resistant marine coatings. Nat Commun Online. 2; Article ID 244. doi: 10.1038/ncomms1251.

Callow ME, Callow JA, Pickett-Heaps JD, Wetherbee R. 1997. Primary adhesion of Enteromorpha (Chlorophyta, Ulvales) propagules: Quantitative settlement studies and video microscopy. J Phycol. 33:938-947.

Callow ME, Callow JE. 2002. Marine biofouling: a sticky problem. Biologist (London). 49:10-14.

Chang Y, Chen WY, Yandi W, Shih YJ, Chu WL, Liu YL, Chu CW, Ruaan RC, Higuchi A. 2009. Dual-Thermoresponsive Phase Behavior of Blood Compatible Zwitterionic Copolymers Containing Nonionic Poly(N-isopropyl acrylamide). Biomacromolecules. 10:2092-2100.

Chang Y, Yandi W, Chen WY, Shih YJ, Yang CC, Chang Y, Ling QD, Higuchi A. 2010. Tunable Bioadhesive Copolymer Hydrogels of Thermoresponsive Poly(N-isopropyl acrylamide) Containing Zwitterionic Polysulfobetaine. Biomacromolecules. 11:1101-1110.

Chapman RG, Ostuni E, Takayama S, Holmlin RE, Yan L, Whitesides GM. 2000. Surveying for surfaces that resist the adsorption of proteins. J Am Chem Soc. 122:8303-8304. 
Chen SF, Li LY, Zhao C, Zheng J. 2010. Surface hydration: Principles and applications toward low-fouling/nonfouling biomaterials. Polymer. 51:5283-5293.

Christensen BE. 1989. The Role of Extracellular Polysaccharides in Biofilms. J Biotechnol. 10:181-201.

Clare AS, Hoeg JT. 2008. Balanus amphitrite or Amphibalanus amphitrite? A note on barnacle nomenclature. Biofouling. 24:55-57.

Di Fino A, Petrone L, Aldred N, Ederth T, Liedberg B, Clare AS. 2014. Correlation between surface chemistry and settlement behaviour in barnacle cyprids (Balanus improvisus). Biofouling. 30:143-152.

Dobretsov S, Abed RMM, Teplitski M. 2013. Mini-review: Inhibition of biofouling by marine microorganisms. Biofouling. 29:423-441.

Ederth T, Nygren P, Pettitt ME, Ostblom M, Du C, Broo K, Callow ME, Callow J, Liedberg B. 2008. Anomalous settlement behavior of Ulva linza zoospores on cationic oligopeptide surfaces. Biofouling. 24:303-312.

Ederth T, Pettitt ME, Nygren P, Du CX, Ekblad T, Zhou Y, Falk M, Callow ME, Callow JA, Liedberg B. 2009. Interactions of Zoospores of Ulva linza with ArginineRich Oligopeptide Monolayers. Langmuir. 25:9375-9383.

Ekblad T, Bergstroem G, Ederth T, Conlan SL, Mutton R, Clare AS, Wang S, Liu YL, Zhao Q, D'Souza F, Donnelly GT, Willemsen PR, Pettitt ME, Callow ME, Callow JA, Liedberg B. 2008. Poly(ethylene glycol)-Containing Hydrogel Surfaces for Antifouling Applications in Marine and Freshwater Environments. Biomacromolecules. 9:2775-2783.

Ferreira L, Zumbuehl A. 2009. Non-leaching surfaces capable of killing microorganisms on contact. J Mater Chem. 19:7796-7806.

Fitridge I, Dempster T, Guenther J, de Nys R. 2012. The impact and control of biofouling in marine aquaculture: a review. Biofouling. 28:649-669.

Fusetani N. 2004. Biofouling and antifouling. Nat Prod Rep. 21:94-104.

Guo QQ, Cai XB, Wang XL, Yang J. 2013. "Paintable" 3D printed structures via a postATRP process with antimicrobial function for biomedical applications. J Mater Chem B. 1:6644-6649.

Hadfield MG. 2011. Biofilms and Marine Invertebrate Larvae: What Bacteria Produce That Larvae Use to Choose Settlement Sites. Annual Review of Marine Science. 3:453-470. 
Hadfield MG, Paul VJ. 2001. Natural chemical cues for settlement and metamorphosis of marine invertebrate larvae. In: Marine Chemical Ecology, McClintock JB, Baker BJ (Eds). CRC Press, Boca Raton, p. 431-461.

Hellio C, Yebra D editors. 2009. Advances in marine antifouling caotings and technologies. Cambridge, UK: Woodhead Publishing Limited,.

Ista LK, Fan HY, Baca O, Lopez GP. 1996. Attachment of bacteria to model solid surfaces: Oligo(ethylene glycol) surfaces inhibit bacterial attachment. Fems Microbiol Lett. 142:59-63.

Ista LK, Perez-Luna VH, Lopez GP. 1999. Surface-grafted, environmentally sensitive polymers for biofilm release. Appl Environ Microb. 65:1603-1609.

Jansen JFGA, Dias AA, Dorschu M, Coussens B. 2003. Fast monomers: Factors affecting the inherent reactivity of acrylate monomers in photoinitiated acrylate polymerization. Macromolecules. 36:3861-3873.

Joint I, Tait K, Callow ME, Callow JA, Milton D, Williams P, Cámara M. 2002. Cellto-cell communication across the prokaryote-eukaryote boundary. Science. 298:1207.

Karamdoust S, Yu BY, Bonduelle CV, Liu Y, Davidson G, Stojcevic G, Yang J, Lau WM, Gillies ER. 2012. Preparation of antibacterial surfaces by hyperthermal hydrogen induced cross-linking of polymer thin films. J Mater Chem. 22:48814889.

Kirschner CM, Brennan AB. 2012. Bio-Inspired Antifouling Strategies. Annu Rev Mater Res. 42:211-229.

Krishnan S, Finlay J, Hexemer A, Wang N, Ober C, Kramer EJ, Callow ME, Callow JA, Fischer D. 2005. Interaction of Ulva and Navicula marine algae with surfaces of pyridinium polymers with fluorinated side-chains. Abstr Pap Am Chem S. 230:U4290-U4291.

Larsson A, Ekblad T, Andersson O, Liedberg B. 2007. Photografted poly(ethylene glycol) matrix for affinity interaction studies. Biomacromolecules. 8:287-295.

Lee H, Son SH, Sharma R, Won Y-Y. 2011. A Discussion of the pH-Dependent Protonation Behaviors of Poly(2-(dimethylamino)ethyl methacrylate) (PDMAEMA) and Poly(ethylenimine-ran-2-ethyl-2-oxazoline) (P(EI-r-EOz)). The Journal of Physical Chemistry B. 115:844-860. 
Lee HH, Ruzele Z, Malysheva L, Onipko A, Gutes A, Bjorefors F, Valiokas R, Liedberg B. 2009. Long-Chain Alkylthiol Assemblies Containing Buried InPlane Stabilizing Architectures. Langmuir. 25:13959-13971.

Lee SB, Koepsel RR, Morley SW, Matyjaszewski K, Sun YJ, Russell AJ. 2004. Permanent, nonleaching antibacterial surfaces. 1. Synthesis by atom transfer radical polymerization. Biomacromolecules. 5:877-882.

Lei HY, Wang MM, Tang ZC, Luan YF, Liu W, Song B, Chen H. 2014. Control of Lysozyme Adsorption by $\mathrm{pH}$ on Surfaces Modified with Polyampholyte Brushes. Langmuir. 30:501-508.

Lejars M, Margaillan A, Bressy C. 2012. Fouling Release Coatings: A Nontoxic Alternative to Biocidal Antifouling Coatings. Chemical Reviews. 112:43474390.

Li P, Poon YF, Li WF, Zhu HY, Yeap SH, Cao Y, Qi XB, Zhou CC, Lamrani M, Beuerman RW, Kang ET, Mu YG, Li CM, Chang MW, Leong SSJ, Chan-Park MB. 2011. A polycationic antimicrobial and biocompatible hydrogel with microbe membrane suctioning ability. Nat Mater. 10:149-156.

Liu GM, Wu D, Ma CC, Zhang GZ, Wang HF, Yang SH. 2007. Insight into the origin of the thermosensitivity of poly[2-(dimethylamino)ethyl methacrylate]. Chemphyschem. 8:2254-2259.

Lord MS, Stenzel MH, Simmons A, Milthorpe BK. 2006. The effect of charged groups on protein interactions with poly(HEMA) hydrogels. Biomaterials. 27:567-575.

Maleshlijski S, Sendra GH, Aldred N, Clare AS, Liedberg B, Grunze M, Ederth T, Rosenhahn A. Imaging SPR combined with stereoscopic 3D tracking to study barnacle cyprid-surface interactions. Surface Science, Surface Science. 643:172-177, DOI: 101016/jsusc201508027.

Marshall K, Joint I, Callow ME, Callow JA. 2006. Effect of marine bacterial isolates on the growth and morphology of axenic plantlets of the green alga Ulva linza. Microbial Ecology. 52:302-310.

Meuler AJ, Chhatre SS, Nieves AR, Mabry JM, Cohen RE, McKinley GH. 2011. Examination of wettability and surface energy in fluorodecyl POSS/polymer blends. Soft Matter. 7:10122-10134.

Mieszkin S, Callow ME, Callow JA. 2013. Interactions between microbial biofilms and marine fouling algae: a mini review. Biofouling. 29:1097-1113. 
Mieszkin S, Martin-Tanchereau P, Callow ME, Callow JA. 2012. Effect of bacterial biofilms formed on fouling-release coatings from natural seawater and Cobetia marina, on the adhesion of two marine algae. Biofouling. 28:953-968.

Mitik-Dineva N, Wang J, Truong VK, Stoddart PR, Malherbe F, Crawford RJ, Ivanova EP. 2009. Differences in colonisation of five marine bacteria on two types of glass surfaces. Biofouling. 25:621-631.

Ostuni E, Chapman RG, Holmlin RE, Takayama S, Whitesides GM. 2001. A survey of structure-property relationships of surfaces that resist the adsorption of protein. Langmuir. 17:5605-5620.

Ouchi M, Badi N, Lutz JF, Sawamoto M. 2011. Single-chain technology using discrete synthetic macromolecules. Nat Chem. 3:917-924.

Owens DK, Wendt RC. 1969. Estimation of the surface free energy of polymers. Journal of Applied Polymer Science. 13:1741-1747.

Patel P, Callow ME, Joint I, Callow JA. 2003. Specificity in the settlement - Modifying response of bacterial biofilms towards zoospores of the marine alga Enteromorpha. Environmental Microbiology. 5:338-349.

Petrone L, Di Fino A, Aldred N, Sukkaew P, Ederth T, Clare AS, Liedberg B. 2011. Effects of surface charge and Gibbs surface energy on the settlement behaviour of barnacle cyprids (Balanus amphitrite). Biofouling. 27:1043-1055.

Petrone L, Aldred N, Emami K, Enander K, Ederth T, Clare AS. 2014. Chemistry-specific surface adsorption of the barnacle settlement-inducing protein complex. R Soc Interface Focus. 5: Article ID 20140047. doi: 10.1098/rsfs.2014.0047.

Poulsen N, Kröger N, Harrington MJ, Brunner E, Paasch S, Buhmann MT. 2014. Isolation and biochemical characterization of underwater adhesives from diatoms. Biofouling. 30:513-523.

Pranzetti A, Salaun S, Mieszkin S, Callow ME, Callow JA, Preece JA, Mendes PM. 2012. Model Organic Surfaces to Probe Marine Bacterial Adhesion Kinetics by Surface Plasmon Resonance. Adv Funct Mater. 22:3672-3681.

Quere D. 2008. Wetting and roughness. Annual Review of Materials Research. 38:7199.

Ramstedt M, Cheng N, Azzaroni O, Mossialos D, Mathieu HJ, Huck WTS. 2007. Synthesis and characterization of poly(3-sulfopropylmethacrylate) brushes for potential antibacterial applications. Langmuir. 23:3314-3321. 
Rawlinson LAB, Ryan SM, Mantovani G, Syrett JA, Haddleton DM, Brayden DJ. 2010. Antibacterial Effects of Poly(2-(dimethylamino ethyl)methacrylate) against Selected Gram-Positive and Gram-Negative Bacteria. Biomacromolecules. 11:443-453.

Rickert E, Karsten U, Pohnert G, Wahl M. 2015. Seasonal fluctuations in chemical defenses against macrofouling in Fucus vesiculosus and Fucus serratus from the Baltic Sea. Biofouling. 31:363-377.

Rittschof D. 2010. Research on environmentally benign antifouling coatings. In: Biofouling; Durr S, Thomason JC (Eds.). Oxford: Wiley-Blackwell. p. 396-409. Rosenhahn A, Finlay JA, Pettit ME, Ward A, Wirges W, Gerhard R, Callow ME, Grunze M, Callow JA. 2009. Zeta potential of motile spores of the green alga Ulva linza and the influence of electrostatic interactions on spore settlement and adhesion strength. Biointerphases. 4:7-11.

Rosenhahn A, Schilp S, Kreuzer HJ, Grunze M. 2010. The role of "inert" surface chemistry in marine biofouling prevention. Phys Chem Chem Phys. 12:42754286.

Roudman AR, DiGiano FA. 2000. Surface energy of experimental and commercial nanofiltration membranes: Effects of wetting and natural organic matter fouling. J Membrane Sci. 175:61-73.

Schilp S, Kueller A, Rosenhahn A, Grunze M, Pettitt ME, Callow ME, Callow JA. 2007. Settlement and adhesion of algal cells to hexa (ethylene glycol)containing self-assembled monolayers with systematically changed wetting properties. Biointerphases. 2:143-150.

Schilp S, Rosenhahn A, Pettitt ME, Bowen J, Callow ME, Callow JA, Grunze M. 2009. Physicochemical Properties of (Ethylene Glycol)-Containing Self-Assembled Monolayers Relevant for Protein and Algal Cell Resistance. Langmuir. 25:10077-10082.

Schmitt A, Varoqui R, Uniyal S, Brash JL, Pusineri C. 1983. Interaction of Fibrinogen with Solid-Surfaces of Varying Charge and Hydrophobic Hydrophilic Balance .1. Adsorption-Isotherms. J Colloid Interf Sci. 92:25-34.

Schultz MP, Bendick JA, Holm ER, Hertel WM. 2011. Economic impact of biofouling on a naval surface ship. Biofouling. 27:87-98. 
Schultz MP, Finlay JA, Callow ME, Callow JA. 2000. A turbulent channel flow apparatus for the determination of the adhesion strength of microfouling organisms. Biofouling. 15:243-251.

Spori DM, Drobek T, Zurcher S, Ochsner M, Sprecher C, Muehlebach A, Spencer ND. 2008. Beyond the lotus effect: Roughness, influences on wetting over a wide surface-energy range. Langmuir. 24:5411-5417.

Svetlicic V, Zutic V, Pletikapic G, Radic TM. 2013. Marine Polysaccharide Networks and Diatoms at the Nanometric Scale. Int J Mol Sci. 14:20064-20078.

Thome I, Bauer S, Vater S, Zargiel K, Finlay JA, Arpa-Sancet MP, Alles M, Callow JA, Callow ME, Swain GW, Grunze M, Rosenhahn A. 2014. Conditioning of self-assembled monolayers at two static immersion test sites along the east coast of Florida and its effect on early fouling development. Biofouling. 30:10111021.

Tiller JC, Liao CJ, Lewis K, Klibanov AM. 2001. Designing surfaces that kill bacteria on contact. P Natl Acad Sci USA. 98:5981-5985.

Wahl M, Kroger K, Lenz M. 1998. Non-toxic protection against epibiosis. Biofouling. 12:205-226.

Wasilewska M, Adamczyk Z. 2011. Fibrinogen Adsorption on Mica Studied by AFM and in Situ Streaming Potential Measurements. Langmuir. 27:686-696.

Vater SM, Finlay J, Callow ME, Callow JA, Ederth T, Liedberg B, Grunze M, Rosenhahn A. 2015. Holographic microscopy provides new insights into the settlement of zoospores of the green alga Ulva linza on cationic oligopeptide surfaces. Biofouling. 31:229-239.

Wibisono Y, Yandi W, Golabi M, Nugraha R, Cornelissen ER, Kemperman AJB, Ederth T, Nijmeijer K. 2015. Hydrogel-coated feed spacers in two-phase flow cleaning in spiral wound membrane elements: A novel platform for eco-friendly biofouling mitigation. Water Res. 71:171-186.

Vinsova J, Vavrikova E. 2008. Recent advances in drugs and prodrugs design of chitosan. Curr Pharm Design. 14:1311-1326.

Xie LY, Hong F, He CX, Ma CF, Liu JH, Zhang GZ, Wu C. 2011. Coatings with a selfgenerating hydrogel surface for antifouling. Polymer. 52:3738-3744.

Yandi W, Mieszkin S, Callow ME, Callow JA, Finlay J, Liedberg B, Ederth T. Antialgal activity of poly(2-(dimethylamino)ethyl methacrylate) brushes against the marine alga Ulva. Submitted to Biomacromolecules. 
Yandi W, Mieszkin S, Martin-Tanchereau P, Callow ME, Callow JA, Tyson L, Liedberg B, Ederth T. 2014. Hydration and Chain Entanglement Determines the Optimum Thickness of Poly(HEMA-co-PEG(10)MA) Brushes for Effective Resistance to Settlement and Adhesion of Marine Fouling Organisms. ACS Appl Mater Inter. 6:11448-11458.

Yang WJ, Neoh KG, Kang ET, Lee SSC, Teo SLM, Rittschof D. 2012. Functional polymer brushes via surface-initiated atom transfer radical graft polymerization for combating marine biofouling. Biofouling. 28:895-912.

Yudovin-Farber I, Golenser J, Beyth N, Weiss EI, Domb AJ. 2010. Quaternary Ammonium Polyethyleneimine: Antibacterial Activity. J Nanomater. 2010: Article ID 826343. DOI: 10.1155/2010/826343.

Zardus JD, Nedved BT, Huang Y, Tran C, Hadfield MG. 2008. Microbial biofilms facilitate adhesion in biofouling invertebrates. Biological Bulletin. 214:91-98.

Zhang Z, Finlay JA, Wang LF, Gao Y, Callow JA, Callow ME, Jiang SY. 2009. Polysulfobetaine-Grafted Surfaces as Environmentally Benign Ultralow Fouling Marine Coatings. Langmuir. 25:13516-13521. 